\title{
Assessment and treatment of preoperative anemia: Continuing Professional Development
}

\author{
Gregory M. T. Hare, MD, PhD · James E. Baker, MD • \\ Katerina Pavenski, MD
}

Received: 26 December 2010/ Accepted: 18 March 2011/Published online: 12 April 2011

(C) Canadian Anesthesiologists' Society 2011

\begin{abstract}
Purpose The purpose of this continuing professional development (CPD) module is to review the risk of anemia and transfusion in perioperative patients and to propose an approach for the diagnosis and treatment of preoperative anemia.

Principal findings Preoperative anemia has been associated with increased transfusion of red blood cells, organ injury, and mortality. Postoperative anemia has also been associated with impaired recovery from surgery. Transfusion also increases the risk of infection, organ injury, and mortality. Preoperatively, iron deficiency anemia can be corrected with oral or intravenous iron; certain types of patients might respond to administration of erythrocyte stimulating agents (ESAs). With ESAs, the increased risk of thrombosis should be balanced against the expected benefit.

Conclusions Preoperative diagnosis and treatment of anemia may reduce the risk of morbidity and mortality associated with both anemia and transfusion.
\end{abstract}

G. M. T. Hare, MD, PhD ( $ه)$

Department of Anesthesia and Physiology, The Keenan Research Centre in the Li Ka Shing Knowledge Institute, St. Michael's Hospital, University of Toronto, 30 Bond Street,

Toronto, ON M5B 1W8, Canada

e-mail: hareg@smh.ca

\section{J. E. Baker, MD}

Department of Anesthesia, St. Michael's Hospital,

University of Toronto, Toronto, ON, Canada

K. Pavenski, MD

Department of Laboratory Medicine, St. Michael's Hospital, University of Toronto, Toronto, ON, Canada
Objectives of this Continuing Professional Development (CPD) module

After reading this module, the reader should be able to:

1. Understand the risk of anemia in perioperative patients who undergo cardiac and non-cardiac surgery;

2. Review the risk of transfusion;

3. Have a clear approach to the diagnosis and treatment of iron deficiency anemia; and

4. Evaluate the potential role of erythrocyte stimulating agents in the treatment of anemia of chronic disease.

An increasing number of clinical studies have demonstrated that anemia and its treatments are associated with morbidity and mortality in perioperative patients. ${ }^{1-4}$ Chronic anemia may be of multifactorial etiology and is frequent in patients presenting for elective surgery. For example, preoperative anemia may be present in up to $75 \%$ of patients presenting for elective surgery, and close to $90 \%$ of patients may have postoperative anemia. ${ }^{5}$ Iron deficiency and anemia of chronic disease are the causes of anemia in a high proportion of these patients. ${ }^{6-11}$ Chronic anemia is a risk factor for acute intraoperative anemia that frequently results from a combination of acute blood loss and hemodilution secondary to fluid resuscitation (hemodilution). The increase in mortality associated with anemia has been characterized in different patient populations, including those undergoing surgery, ${ }^{1-3}$ those with cardiovascular disease, ${ }^{12}$ and critically ill patients following neurotrauma. ${ }^{13}$ Cumulative evidence from clinical studies suggests that anemia-induced injury to vital organs, including the brain, kidney, and heart, may be responsible for the observed increase in mortality. ${ }^{4}$ The magnitude of this clinical problem is further accentuated by growing evidence that the main treatment strategy for acute anemia 
(allogeneic blood transfusion) is also associated with an increase in mortality. ${ }^{14-17}$ Therefore, diagnosis and treatment of acute or chronic anemia prior to elective surgery may improve patient outcomes by reducing morbidity and mortality associated with both anemia and allogeneic red blood cell transfusion.

\section{The risk of preoperative anemia}

Anemia is an independent risk factor for adverse outcomes in patients undergoing cardiac and non-cardiac surgery. ${ }^{1-3}$ While the key consequence of acute anemia is reduced blood $\mathrm{O}_{2}$ content leading to reduced tissue $\mathrm{O}_{2}$ delivery, the mechanism(s) of increased organ dysfunction and mortality have not been clearly defined. However, recent experimental studies have demonstrated that acute anemia can result in a reduction in tissue partial pressure of oxygen $\left(\mathrm{PO}_{2}\right)$, which supports the hypothesis that tissue hypoxia is a significant mechanism of anemia-induced organ injury and morbidity. ${ }^{18}$ During anemia, tissue hypoxia occurs in a hierarchical manner: organs that are critically important for survival (heart, brain) receive preferential oxygen delivery and maintain tissue "normoxia" at very low hemoglobin (Hb) levels $\left(\sim 35\right.$ to $\left.40 \mathrm{~g} \cdot \mathrm{L}^{-1}\right)$. Conversely, less vital organs (kidney, liver, intestine) become hypoxic at a much higher $\mathrm{Hb}$ level ( 60 to $\left.70 \mathrm{~g} \cdot \mathrm{L}^{-1}\right) .{ }^{4}$ In addition, intraoperative hemodilution increases the risk of organ injury (brain, kidney) and mortality. ${ }^{2-4}$ However, the Hb thresholds for organ injury and mortality for individual patients are not known. While some patients tolerate $\mathrm{Hb}$ levels near $70 \mathrm{~g} \cdot \mathrm{L}^{-1}$, in others, mortality and neurological injury is increased following cardiopulmonary bypass near this threshold. ${ }^{19,20}$ Indeed, the optimal $\mathrm{Hb}$ threshold may be even higher $\left(100 \mathrm{~g} \cdot \mathrm{L}^{-1}\right)$ for patients suffering from neurotrauma or acute coronary syndromes. ${ }^{21,22}$

\section{The physiological response to anemia}

Acute anemia provides a primary "hypoxic" stimulus by decreasing blood oxygen content and reducing oxygen delivery to tissue. Tissue hypoxia is detected by specific "hypoxic" sensors at the cellular level. This is demonstrated by an increase in hypoxia inducible factor, ${ }^{23}$ by vascular chemoreceptors, and by specific organs, such as the kidney, that use these cellular mechanisms. Cellular detection of tissue hypoxia triggers an increase in autonomic responses that result in acute increases in cardiac output and reduction in systemic vascular resistance to optimize tissue oxygen delivery. ${ }^{24}$ Concurrently, oxygen extraction is increased, mediated, in part, by a right shift in the oxyhemoglobin dissociation curve. The increased cardiac output is distributed differentially in a hierarchical manner such that critically vital organs (brain, heart) receive proportionally more oxygen relative to less vital organs (kidney, gut). Although myocardial oxygen consumption increases (increased heart rate and contractility), an overall reduction in metabolic requirement in other tissues helps to balance oxygen supply and demand., ${ }^{4,25}$ Interfering with either the increase in cardiac output or local organ specific vasodilation may disrupt tissue oxygen delivery during acute hemodilution. ${ }^{18,26}$ This may explain the observed increase in perioperative ischemic events in $\beta$-blockade patients. $^{27-29}$

\section{Clinical evidence of impaired oxygen delivery during anemia}

Clinical and experimental studies assessing the impact of acute hemodilution anemia have demonstrated that the cardiovascular responses to acute anemia are remarkably similar across species. ${ }^{4,24,25}$ These responses include an increase in cardiac output with organ specific vasodilation to reduce systemic vascular resistance and maintain global oxygen delivery. Despite these compensatory cardiovascular responses, evidence suggests that brain oxygen delivery is inadequate during severe anemia $(\mathrm{Hb} \sim 50$ to $60 \mathrm{~g} \cdot \mathrm{L}^{-1}$ ), resulting in reduced brain tissue $\mathrm{PO}_{2}$ and increased hypoxic cellular responses. ${ }^{23}$ Inadequate brain oxygen delivery may be responsible for the observed decline in cognitive function during severe anemia. ${ }^{30}$ In surgical patients, low admission and discharge $\mathrm{Hb}$ levels have also been associated with increased postoperative mortality, increased major adverse cardiovascular events, increased length of hospital stay, readmission, reduced quality of life, and impaired functional recovery. ${ }^{1,27,31-33}$

\section{Risk of therapies that impair the cardiovascular responses to anemia ( $\beta$-blockade)}

The recent publication of the POISE trial emphasized the paradoxical potential for cerebral injury despite myocardial protection in acutely $\beta$-blocked patients undergoing non-cardiac surgery. ${ }^{28}$ The risk of stroke was increased by about twofold in $\beta$-blocked patients who experienced intraoperative bleeding, suggesting a potential interaction between acute anemia and $\beta$-blockade. A subsequent retrospective analysis assessed the impact of a reduction in $\mathrm{Hb}$ levels on adverse outcomes and demonstrated a paradoxical increase in acute cardiac events in $\beta$-blocked patients. $^{27}$ These data suggest that $\beta$-blockade may have prevented the adequate delivery of oxygen to the 
myocardium during acute intraoperative anemia. An additional study identified an increase in perioperative myocardial infarction in $\beta$-blocked patients who experienced blood loss and $\mathrm{Hb}$ levels below $100 \mathrm{~g} \cdot \mathrm{L}^{-1} \cdot{ }^{29}$ Thus, treatment with $\beta$-blockers may accentuate the risk of organ ischemia (brain, heart) in the setting of acute blood loss. The mechanism may involve global impairment in the cardiac output response and impaired microvascular dilation, as supported by experimental studies demonstrating that $\beta_{1}$-blockade impaired cardiac output ${ }^{18}$ and $\beta_{2}$-blockade impaired cerebral vasodilation during acute anemia. ${ }^{26}$

\section{Current trends in red blood cell transfusion}

The ongoing debate regarding the risk and benefit of red blood cell transfusions was initiated over 150 years ago in western medical societies. ${ }^{34}$ Our understanding of the potential risks associated with red blood cell transfusion has been punctuated recently by specific events, such as the increased incidence of transmission of viral disease in the $1980 \mathrm{~s}$, leading to a reduced confidence in the supply of banked blood and promotion of transfusion avoidance. ${ }^{35}$ With the risk of transfusion-related morbidity and mortality in mind, three randomized trials in adults and children have demonstrated that lower $\mathrm{Hb}$ thresholds were well-tolerated in critically ill patients and cardiac surgical patients. ${ }^{14,36}$ Furthermore, the physiological premise that acute hemodilution optimized blood rheology and favoured perfusion led to clinical approaches that further reduced red cell mass in a number of clinical settings. ${ }^{4}$ The collective impact of these influences promoted a clinical attitude of tolerance for acute and chronic anemia. However, the validity of some of these studies has been questioned. Further transfusion threshold trials are currently underway to provide evidence for or against more liberal transfusion therapies in high-risk patient populations. ${ }^{37}$

\section{The goal of red blood cell transfusions}

Treatment of tissue hypoxia remains one of the primary indications to transfuse red blood cells in order to restore adequate tissue oxygen delivery. However, our ability to detect tissue hypoxia and the impact of red cell transfusion are limited in the clinical setting. Newer methods for assessing adequacy of tissue oxygen delivery before and after red cell transfusion may help guide clinical decisions. For example, near infrared spectroscopy, ${ }^{38}$ positron emission tomography, ${ }^{39}$ and invasive oxygen electrodes ${ }^{40}$ have provided some insight into the ability of red cell transfusions to improve tissue oxygen tension. While some studies demonstrate improved oxygen delivery and tissue $\mathrm{PO}_{2}$ with transfusion, ${ }^{40}$ other studies do not. ${ }^{38}$ The lack of a consistent response to transfusion of stored blood may be influenced by the effect of blood storage. ${ }^{16,41}$ In some studies, increased incidence of mortality has been associated with the transfusion of blood stored for longer periods of time. ${ }^{16}$ Despite these issues, transfusion of red blood cells is still regarded as lifesaving in the setting of severe acute blood loss. ${ }^{42}$

\section{The risk of transfusion of red blood cells}

Red blood cell transfusion continues to be the only effective means of treating acute severe intraoperative blood loss. Allogeneic blood transfusion is associated with infectious and non-infectious risks (Table). ${ }^{43}$ Infectious risks include the risks related to transmission of various agents, such as viruses, bacteria, and protozoa. While the risks of transmitting viral infections, such as the human immunodeficiency virus (HIV) or hepatitis C virus, by transfusion are extremely low (e.g., in Canada, the risk of transfusion-transmitted HIV is estimated at 1 in 7.8 million $){ }^{44}$ the emergence of new blood-borne pathogens (example Chikungunya virus) represent a growing concern to the blood supply. Non-infectious risks of transfusion represent a larger proportion of adverse events. These can be minor (i.e., urticaria) or severe (i.e., anaphylactic reaction). According to the 2009 Food and Drug Administration (FDA) report, the top causes of transfusion-related mortality are transfusion-related acute lung injury, hemolytic transfusion reactions, and transfusion-associated circulatory overload. Multiple studies have shown an association of allogeneic blood transfusion with postoperative infections, prolonged hospital stay, and morbidity and mortality. ${ }^{13-17,43}$ Moreover, allogeneic blood transfusion has been associated with increased risk of thrombotic events ${ }^{45}$ and decreased disease-free survival in cancer patients. ${ }^{46}$ In fact, in a systematic review completed by Marik et al., the risks of transfusion were found to outweigh the benefits in 42 out of 45 of the studies evaluated. ${ }^{47}$ Regardless of the efficacy of maintaining intravascular volume and blood oxygen-carrying capacity, red cell transfusion carries a number of risks. Decisions to transfuse should be based on clinical and laboratory data, and available alternatives should be considered.

\section{Diagnosis and treatment of anemia}

Given the bulk of the evidence supporting that both anemia and red blood cell transfusions are associated with increased morbidity and mortality, a strategy to minimize both conditions may improve patient outcomes significantly. 
Table Risk of Transfusion

\begin{tabular}{|c|c|c|}
\hline Risk of Transfusion & Severity & Incidence \\
\hline Febrile non-hemolytic transfusion reaction & Mild & 1 in 300 donor $\mathrm{RBC}$ \\
\hline Allergic reaction & Mild to severe & $\begin{array}{l}1 \text { in } 100 \text { minor allergic reaction } \\
1 \text { in } 40,000 \text { serious allergic reaction }\end{array}$ \\
\hline \multicolumn{3}{|l|}{ Infection: } \\
\hline Bacteria & Mild to severe & 1 in 500,000 \\
\hline Viruses & Severe & $\begin{array}{l}\text { HIV } 1 \text { in } 7,800,000 \\
\mathrm{HCV} 1 \text { in } 2,300,000 \\
\mathrm{HBV} 1 \text { in } 153,000 \\
\mathrm{HTLV} 1 \text { in } 5,000,000 \\
\text { WNV } 1 \text { in } 1,000,000\end{array}$ \\
\hline Others (protozoa, prions) & Severe & Unknown \\
\hline Emerging pathogens & Unknown & Unknown \\
\hline Mistransfusion & Mild to severe & $\begin{array}{l}1 \text { in } 1,000 \text { near miss events } \\
1 \text { in } 15,000 \text { wrong blood given to recipient } \\
1 \text { in } 40,000 \text { wrong blood given to recipient is } \mathrm{ABO} \text { incompatible } \\
1 \text { in } 1,000,000 \text { fatal acute hemolytic transfusion reaction }\end{array}$ \\
\hline Transfusion-related acute lung injury & Severe & 1 in 30,000 units \\
\hline Transfusion-associated circulatory overload & Moderate to severe & 1 in 700 transfusion episodes \\
\hline Immunomodulation & Mild to severe & Unknown \\
\hline Death & Severe & 1 in $1,800,000$ to $5,600,000$ \\
\hline
\end{tabular}

Sources: O'Brien et al. ${ }^{44}$ Vamvakas et al ${ }^{43}$

$\mathrm{RBC}=$ red blood cells; HIV = human immunodeficiency virus; $\mathrm{HCV}=$ hepatitis $\mathrm{C}$ virus; $\mathrm{HBV}=$ hepatitis $\mathrm{B}$ virus; HTLV $=$ Human $\mathrm{T}$-cell leukemia/lymphoma virus; WNV = West Nile virus

Therefore, the diagnosis and successful treatment of anemia in patients scheduled to undergo elective surgery may provide such an approach, as reviewed recently ${ }^{11}$ and advocated by the Network for Advancement of Transfusion Alternatives (Figure). This approach has been based on the evidence that: 1) a high proportion of patients are anemic when presenting for surgery; 2) the majority of cases of anemia are treatable (nutritional deficiency, blood loss, anemia of chronic disease); and 3) successful treatment of anemia results in transfusion avoidance. ${ }^{48,49}$

Any preoperative patient with anemia may be evaluated easily with a complete blood cell count, ferritin, vitamin B12, and red blood cell folate. As vitamin B12 and folate deficiencies are more common in older patients, all patients over the age of $65 \mathrm{yr}$ and those at risk for nutritional deficiencies should be evaluated. Deficiencies in both vitamin B12 and folate can be treated successfully with oral medications. Low ferritin invariably points to iron deficiency. Unfortunately, high ferritin does not necessarily indicate that the iron stores are replete. Ferritin is an acute phase reactant and may be elevated in inflammatory states. Serum iron saturation is not a reliable test for assessment of iron deficiency. However, a soluble transferrin receptor may help to differentiate between iron deficiency and anemia of chronic disease. This marker is elevated in iron deficiency and is low or normal in anemia of chronic disease.

Once the diagnosis has been made, iron deficiency can be effectively treated with either oral or intravenous iron. ${ }^{11,50}$ Both preparations have their own benefits and drawbacks, and these have been summarized fully in a number of recent publications. ${ }^{51,52}$ While iron will treat an iron deficiency anemia successfully, anemia of chronic disease may require a combination of iron and erythrocyte stimulating agent (ESA) to improve Hb levels.

\section{Use of ESAs to treat anemia}

The use of ESAs, such as recombinant human erythropoietin, has been studied as a means of accelerating the correction of red cell mass and effectively reducing red blood cell transfusions in patients undergoing cardiac and orthopedic surgery. ${ }^{10,49,53-56}$ In these patient populations, ESAs have been shown to increase $\mathrm{Hb}$ levels, reduce allogeneic transfusion, increase aerobic capacity, and improve quality of life. ${ }^{57}$ The ability of ESAs to reduce transfusions has been balanced by recent concerns of increased adverse outcomes (thrombosis, cancer progression) associated with ESA therapy in patients undergoing spine surgery and in patients with chronic renal failure and 
Figure Approach to the diagnosis and treatment of the anemic patients derived from the cited references and recommendations of the Network for Advancement of Transfusion Alternatives.

$\mathrm{Hb}=$ hemoglobin

concentration;

GFR = glomerular filtration

rate

Figure Approche du diagnostic et du traitement des patients anémiques dérivée des références citées et des recommandations du Réseau pour l'avancement des alternatives à la transfusion (Network for Advancement of Transfusion Alternatives). $\mathrm{Hb}=$ concentration d'hémoglobine; GFR = débit de filtration glomérulaire
Detection, Evaluation \& Management of Preoperative Anemia in Elective Orthopaedic Patients: NATA Guidelines 2010 (Network for Advancement of Transfusion Alternatives)

Hemoglobin Concentration $(\mathrm{Hb})$

$\mathrm{Hb}<120 \mathrm{~g} / \mathrm{L}$ for females, $\mathrm{Hb}<130 \mathrm{~g} / \mathrm{L}$ for males

Evaluation Necessary

Complete Blood Count-Blood Smear, Iron Status, +/- Refer to Hematology

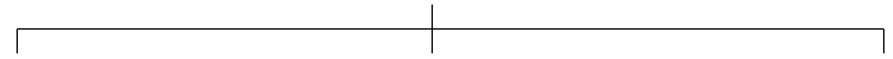

Ferritin $<30 \mu \mathrm{g} / \mathrm{L}$

Ferritin $30-100 \mu \mathrm{g} / \mathrm{L}$

Ferritin $>100 \mu \mathrm{g} / \mathrm{L}$

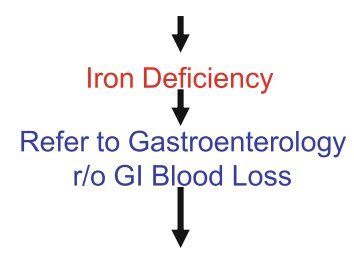

Rule Out Iron Deficiency (Inflammation/Chronic Disease)
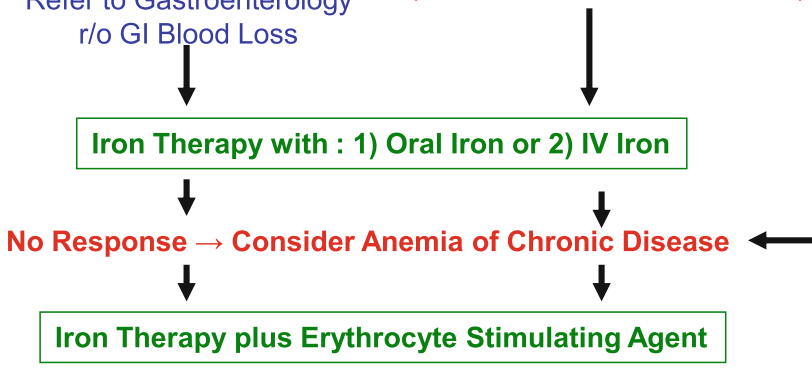

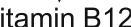

and Folate Level

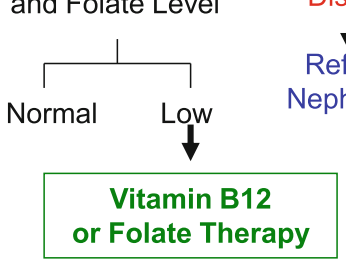

cancer. ${ }^{58-60} \mathrm{~A}$ recent clinical study has suggested that chronic use of high-dose ESA in patients with renal failure may not necessarily improve quality of life or reduce mortality. In fact, the opposite may be true; ESAs may increase the risk of arterial thrombotic events (stroke) and mortality in these patients. ${ }^{57,58}$ These new data have led the FDA to place a black box warning on all ESA products. Also, the FDA recently approved the class-wide Risk Evaluation and Mitigation Strategy for ESAs that requires physicians prescribing ESAs for cancer patients to register and undergo special training.

However, these studies do not support abandoning the treatment of anemia in patients about to undergo elective surgery. In these patients, ESA therapy has been shown to reduce transfusions without a significant increase in the risk of thrombosis. ${ }^{48,53,54}$ Given the potential for adverse events, a graded approach is suggested; ESAs are recommended for unresponsive iron deficiency anemia in which a component of anemia of chronic disease is suspected. ${ }^{10} \mathrm{In}$ addition, clinical studies suggest that brief and/or low-dose treatment of anemic perioperative patients with ESAs may be a safe and effective means of increasing red cell mass and avoiding red cell transfusion. ${ }^{48,49,55}$ Future studies are required to determine if aggressive treatment of anemia can improve patient outcomes following other types of surgery.

Indications of ESAs include major elective surgery associated with significant risk of severe blood loss requiring a transfusion and also in patients who have unresponsive iron deficiency anemia and/or anemia of chronic disease with a pre-treatment $\mathrm{Hb}$ from 100 to $120 \mathrm{~g} \cdot \mathrm{L}^{-1}$. The goal of treatment is to reduce allogeneic blood transfusion and hasten erythroid recovery postoperatively. ${ }^{56}$ An ESA should not be administered to iron deficient patients unless adequate iron supplementation is provided at the same time. The reasons for this are twofold: first, ESAs alone may not be effective in the absence of iron, and second, some studies suggest that ESA-driven erythropoiesis in an iron deficient individual may lead to thrombocytosis and increased risk of thrombosis. The safest $\mathrm{Hb}$ threshold is within a normal $\mathrm{Hb}$ range. Pushing $\mathrm{Hb}$ levels in excess of $140 \mathrm{~g} \cdot \mathrm{L}^{-1}$ may lead to an increase in thrombotic complications. Finally, since the use of ESAs is associated with thrombotic events, appropriate perioperative thromboprophylaxis is imperative.

In conclusion, the combined morbidity and mortality associated with anemia and red cell transfusion suggest that a more aggressive approach be taken with respect to the diagnosis and treatment of anemia in preoperative patients. Treatment of iron deficiency anemia with iron supplements is recommended prior to proceeding with elective surgery associated with increased blood loss. Iron supplementation in combination with ESA may be required to correct nonresponsive anemia and anemia of chronic disease. With ESA therapy, perioperative thromboprophylaxis is required to reduce the risk of venous thrombosis. 


\section{Clinical case}

A 68-yr-old woman is assessed in the pre-admission facility prior to undergoing elective revision of total hip arthroplasty. Her surgeon has scheduled the procedure the following week. Her medical history includes hypertension and a previous myocardial infarction. She had coronary artery bypass grafting six years ago with an internal mammary arterial graft to the left anterior descending artery and a saphenous vein graft to the right coronary artery. She currently has class II angina. Her medications include bisoprolol, fosinopril, and atorvostatin. Laboratory investigation demonstrates a hemoglobin of $90 \mathrm{~g} \cdot \mathrm{L}^{-1}$ but otherwise normal cell counts. A recent echocardiogram reveals grade 2 left ventricular function with inferior hypokinesis, and a persantine thallium study shows a fixed inferior perfusion defect with surrounding inducible perfusion deficits that appear normal on rest images. Cardiology and cardiac surgery consultants have recommended no further treatment.

Instructions for completing the continuing professional development (CPD) module

1. Read the current article and the four references indicated in bold.

2. Go to: https://www.cpass2.umontreal.ca/selfassessment program/ and select the current module (Assessment and treatment of preoperative anemia).

3. Answer the multiple choice questions regarding the case scenario.

4. Once you have entered all of your answers, you will have access to experts' explanations for all the possible choices.

5. Participants may claim up to four hours of CPD, for a total of eight credits under Section 3 of the CPD program of the Royal College of Physicians and Surgeons of Canada.

\section{Évaluation et traitement de l'anémie préopératoire}

\author{
Résumé \\ Objectif L'objectif de ce module de développement \\ professionnel continu (DPC) est de passer en revue le \\ risque de l'anémie et de transfusion chez les patients en \\ période périopératoire et de proposer une approche pour \\ diagnostiquer et traiter l'anémie préopératoire.
}

Constatations principales L'anémie préopératoire a été associée à une augmentation des transfusions d'érythrocytes, des lésions organiques et de la mortalité. L'anémie postopératoire a également été associée à une moins bonne récupération après une chirurgie. Les transfusions augmentent également le risque d'infection, de lésions organiques et de mortalité. En période préopératoire, l'anémie ferriprive peut être corrigée à l'aide de fer administré par voie orale ou intraveineuse; certains types de patients pourraient répondre à l'administration d'agents de stimulation érythrocytaire (ESA). Avec les ESA, le risque accru de thrombose devrait être soupesé en regard des bienfaits escomptés.

Conclusion Le diagnostic et le traitement préopératoires de l'anémie pourraient réduire le risque de morbidité et de mortalité associées à l'anémie et à la transfusion.

\section{Objectifs de ce module de développement professionnel continu (DPC)}

Après avoir lu ce module, le lecteur devrait être en mesure de:

1. comprendre le risque de l'anémie en période périopératoire chez les patients subissant une chirurgie cardiaque et non cardiaque;

2. passer en revue le risque de transfusion;

3. disposer d'une approche claire pour le diagnostic et le traitement de l'anémie ferriprive; et

4. évaluer le rôle potentiel des agents de stimulation érythrocytaire pour le traitement de l'anémie de la maladie chronique.

Un nombre croissant d'études cliniques ont démontré que l'anémie et ses traitements sont associés à une morbidité et une mortalité chez les patients en période périopératoire. ${ }^{1-4}$ L'anémie chronique peut avoir une étiologie multifactorielle et se rencontre souvent chez les patients se présentant pour une chirurgie non urgente. Par exemple, jusqu'à $75 \%$ des patients se présentant pour une chirurgie non urgente peuvent être atteints d'anémie en période préopératoire, et près de $90 \%$ des patients pourraient souffrir d'anémie après la chirurgie. ${ }^{5}$ Chez une grande proportion de ces patients, l'anémie s'explique par une carence en fer ou par une maladie chronique. ${ }^{6-11}$ En période peropératoire, l'anémie chronique est un facteur de risque d'anémie aiguë, qui survient fréquemment en raison d'une combinaison de perte aiguë de sang et d'hémodilution provoquée par la réanimation liquidienne (hémodilution). L'augmentation de la mortalité associée à l'anémie a été décrite chez différentes populations de patients, notamment les patients subissant une chirurgie, ${ }^{1-3}$ les patients souffrant de maladies cardiovasculaires ${ }^{12}$ et les patients gravement malades à la suite d'un neurotraumatisme. ${ }^{13}$ Les données probantes tirées 
d'études cliniques s'accumulent pour suggérer que les lésions provoquées par l'anémie aux organes vitaux, notamment au cerveau, aux reins et au cœur, pourraient être à l'origine de l'augmentation de la mortalité observée. ${ }^{4}$ L'ampleur de ce problème clinique est encore davantage mise en exergue par les données probantes de plus en plus nombreuses soutenant que la principale stratégie de traitement de l'anémie aiguë, soit l'allotransfusion, est également associée à une augmentation de la mortalité. ${ }^{14-17}$ Par conséquent, le diagnostic et le traitement de l'anémie aiguë et chronique avant une chirurgie non urgente pourraient améliorer le pronostic des patients en réduisant la morbidité et la mortalité associées à l'anémie et à l'allotransfusion d'érythrocytes.

\section{Le risque d'anémie préopératoire}

L'anémie est un facteur de risque indépendant de pronostic défavorable chez les patients subissant une chirurgie, qu'elle soit cardiaque ou non cardiaque. ${ }^{1-3}$ Alors que la conséquence principale d'une anémie aiguë est une réduction du contenu d'O $\mathrm{O}_{2}$ dans le sang résultant en un apport réduit d'O $\mathrm{O}_{2}$ aux tissus, le(s) mécanisme(s) sous-jacent(s) à une augmentation du dysfonctionnement des organes et de la mortalité n'ont pas été clairement élucidés. Toutefois, des études expérimentales récentes ont démontré que l'anémie aiguë pouvait entraîner une réduction de la pression partielle d'oxygène $\left(\mathrm{PO}_{2}\right)$ tissulaire, ce qui appuie l'hypothèse que l'hypoxie tissulaire est un important mécanisme de lésion organique et de morbidité induites par l'anémie. ${ }^{18}$ Pendant l'anémie, l'hypoxie tissulaire survient dans un ordre hiérarchique: les organes ayant une importance cruciale pour la survie (cœur, cerveau) bénéficient d'un apport préférentiel en oxygène et maintiennent une 'normoxie' tissulaire à des taux d'hémoglobine $(\mathrm{Hb})$ très bas $\left(\sim 35\right.$ à $\left.40 \mathrm{~g} \cdot \mathrm{L}^{-1}\right)$. En revanche, les organes 'moins' vitaux (reins, foie, intestins) deviennent hypoxiques à un niveau de $\mathrm{Hb}$ beaucoup plus élevé $\left(\sim 60\right.$ à $\left.70 \mathrm{~g} \cdot \mathrm{L}^{-1}\right){ }^{4}$ De plus, l'hémodilution peropératoire augmente le risque de lésion aux organes (cerveau, reins) et de mortalité. ${ }^{2-4}$ Cependant, les seuils de $\mathrm{Hb}$ pour les lésions aux organes et la mortalité ne sont pas connus pour chaque patient. En effet, alors que certains patients tolèrent des niveaux de $\mathrm{Hb}$ avoisinant $70 \mathrm{~g} \cdot \mathrm{L}^{-1}$, chez d'autres, la mortalité et les lésions neurologiques augmentent à la suite d'une circulation extracorporelle avec un niveau proche de ce seuil. ${ }^{19,20}$ En fait, le seuil de $\mathrm{Hb}$ optimal pourrait être encore plus élevé $\left(100 \mathrm{~g} \cdot \mathrm{L}^{-1}\right)$ chez les patients atteints d'un traumatisme neurologique ou de syndromes coronariens aigus. ${ }^{21,22}$

\section{La réponse physiologique à l'anémie}

L'anémie aiguë fournit un stimulus 'hypoxique' primaire en réduisant le contenu d'oxygène dans le sang et l'apport d'oxygène aux tissus. L'hypoxie tissulaire est détectée par des capteurs 'hypoxiques' spécifiques au niveau cellulaire. Cette réaction se manifeste par une augmentation du facteur induit par l'hypoxie, ${ }^{23}$ par les chémorécepteurs vasculaires et par des organes en particulier, comme les reins, qui utilisent ces mécanismes cellulaires. La détection cellulaire de l'hypoxie cellulaire déclenche une augmentation des réponses autonomes qui entraînent des augmentations aiguës du débit cardiaque et une réduction de la résistance vasculaire systémique afin d'optimiser l'apport d'oxygène aux tissus. ${ }^{24}$ L'extraction d'oxygène est simultanément augmentée, médiée en partie par un déplacement vers la droite de la courbe de dissociation de l'oxyhémoglobine. Le débit cardiaque accru est distribué de façon différentielle et hiérarchique, de telle sorte que les organes vitaux cruciaux (cerveau, cœur) reçoivent proportionnellement davantage d'oxygène que les organes moins vitaux (reins, intestins). Bien que la consommation d'oxygène du myocarde augmente (fréquence cardiaque et contractilité accrues), une réduction globale des besoins métaboliques des autres organes aide à équilibrer l'apport et la demande d'oxygène. ${ }^{4,25} \mathrm{Si}$ l'augmentation du débit cardiaque ou la vasodilatation spécifique aux organes locaux est impossible, l'apport d'oxygène aux tissus pourrait être interrompu pendant une hémodilution aiguë. ${ }^{18,26}$ Ceci pourrait expliquer l'augmentation observée d'événements ischémiques périopératoires chez les patients recevant des bêta-bloquants. ${ }^{27-29}$

\section{Données probantes appuyant une détérioration de l'apport d'oxygène pendant l'anémie en clinique}

Les études cliniques et expérimentales évaluant l'impact de l'anémie d'hémodilution aiguë ont démontré que les réactions cardiovasculaires à l'anémie aiguë sont notablement semblables dans toutes les espèces. ${ }^{4,24,25}$ Parmi ces réactions, citons une augmentation du débit cardiaque accompagnée d'une vasodilatation spécifique aux organes afin de réduire la résistance vasculaire systémique et de maintenir l'apport global en oxygène. Malgré ces réactions cardiovasculaires de compensation, des données probantes suggèrent que l'apport d'oxygène au cerveau est inadapté pendant les épisodes d'anémie grave $\left(\mathrm{Hb} \sim 50\right.$ à $\left.60 \mathrm{~g} \cdot \mathrm{L}^{-1}\right)$, entraînant une réduction de la $\mathrm{PO}_{2}$ aux tissus du cerveau et une augmentation des réactions cellulaires hypoxiques. ${ }^{23}$ Un apport inadapté d'oxygène au cerveau pourrait être responsable du déclin de la fonction 
cognitive observé pendant les épisodes d'anémie grave. ${ }^{30}$ Chez les patients chirurgicaux, des taux bas d'admission et de libération de $\mathrm{Hb}$ ont également été associés à une mortalité postopératoire accrue, une augmentation des événements cardiovasculaires défavorables majeurs, une prolongation du séjour hospitalier, une augmentation du taux de réadmission, une réduction de la qualité de vie et une moins bonne récupération fonctionnelle. ${ }^{1,27,31-33}$

\section{Les risques des traitements qui entravent la réponse cardiovasculaire à l'anémie (bêta-bloquants)}

La publication récente de l'étude POISE a souligné le potentiel paradoxal de lésions cérébrales en dépit d'une protection myocardique chez les patients recevant un traitement aigu de bêta-bloquants et subissant une chirurgie non cardiaque. ${ }^{28}$ Le risque d'accident vasculaire cérébral était environ deux fois plus élevé chez les patients bêta-bloqués ayant saigné pendant leur opération, ce qui suggère une interaction potentielle entre l'anémie aiguë et les bêta-bloquants. Une analyse rétrospective subséquente a évalué l'impact d'une réduction des taux de $\mathrm{Hb}$ sur les événements défavorables et démontré une augmentation paradoxale des événements cardiaques aigus chez les patients bêta-bloqués. ${ }^{27}$ Ces données suggèrent que les bêta-bloquants pourraient avoir empêché l'apport adéquat d'oxygène au myocarde pendant les épisodes d'anémie peropératoire aiguë. Une étude supplémentaire a identifié une augmentation des infarctus du myocarde périopératoires chez les patients bêta-bloqués ayant perdu $\mathrm{du}$ sang et manifesté des taux de $\mathrm{Hb}$ inférieurs à $100 \mathrm{~g} \cdot \mathrm{L}^{-1} \cdot{ }^{29}$ Dès lors, le traitement à base de bêta-bloquants pourrait accentuer le risque d'ischémie au niveau de certains organes (cerveau, cœur) dans le cadre de pertes de sang aiguës. Ce mécanisme pourrait être dû en partie à une dégradation globale de la capacité à augmenter le débit cardiaque et à effectuer une dilatation microvasculaire, comme le soutiennent des études expérimentales démontrant que les $\beta_{1}$-bloquants diminuent le débit cardiaque $^{18}$ et les $\beta_{2}$-bloquants entravent la vasodilatation cérébrale pendant les épisodes d'anémie aiguë. ${ }^{26}$

\section{Tendances actuelles en transfusion d'érythrocytes}

Le débat actuel portant sur les avantages et les risques des transfusions d'érythrocytes a été lancé il y a plus de 150 ans dans les sociétés médicales occidentales. ${ }^{34}$ Notre compréhension des risques potentiels associés à la transfusion d'érythrocytes a été récemment ponctuée par des événements en particulier, notamment l'augmentation de l'incidence de transmission de maladies virales dans les années 1980, entraînant des campagnes anti-transfusion et une réduction de la confiance accordée aux produits provenant de banques du sang. ${ }^{35}$ En gardant à l'esprit le risque de morbidité et de mortalité liées aux transfusions, trois études randomisées réalisées chez des adultes et des enfants ont démontré que des seuils de $\mathrm{Hb}$ relativement bas étaient bien tolérés chez les patients gravement malades et chez les patients de chirurgie cardiaque. ${ }^{14,36}$ De plus, le postulat physiologique selon lequel l'hémodilution aiguë optimise la rhéologie sanguine et favorise la perfusion a mené à l'élaboration de plusieurs approches cliniques afin de réduire encore plus la masse érythrocytaire dans plusieurs contextes cliniques. ${ }^{4}$ L'impact cumulatif de ces influences a mené à une attitude clinique de tolérance de l'anémie aiguë et chronique. Cependant, la validité de certaines de ces études a été remise en question. D'autres études portant sur les seuils de transfusion sont actuellement en cours afin d'obtenir des données probantes soutenant ou infirmant le recours à des traitements de transfusion plus libéraux chez les populations de patients à risque élevé. ${ }^{37}$

\section{L'objectif des transfusions d'érythrocytes}

Le traitement de l'hypoxie tissulaire demeure l'une des indications principales de transfusion des érythrocytes afin de rétablir un apport d'oxygène adapté aux tissus. Cependant, notre capacité à détecter l'hypoxie tissulaire et l'impact des transfusions érythrocytaires sont limités dans un contexte clinique. De nouvelles méthodes évaluant la justesse du niveau de l'apport d'oxygène aux tissus avant et après une transfusion d'érythrocytes pourrait contribuer à éclairer les décisions cliniques. Par exemple, la spectroscopie en infrarouge proche, ${ }^{38}$ la tomographie par émission de positrons ${ }^{39}$ et les électrodes oxygène effractives ont offert quelques perspectives quant à la capacité des transfusions d'érythrocytes à améliorer la tension d'oxygène tissulaire. Alors que certaines études démontrent un meilleur apport d'oxygène et une $\mathrm{PO}_{2}$ tissulaire améliorée avec les transfusions, ${ }^{40}$ d'autres ne confirment pas ces bienfaits. ${ }^{38}$ Le manque de réponse constante à la transfusion de sang stocké pourrait être influencé par l'effet de la conservation du sang. ${ }^{16,41}$ Dans certaines études, une incidence accrue de mortalité a été associée à la transfusion de sang conservé pour des périodes prolongées. ${ }^{16}$ Malgré ces inquiétudes, la transfusion d'érythrocytes est encore considérée comme une mesure qui sauve des vies dans le contexte d'une perte de sang aiguë grave. ${ }^{42}$ 


\section{Le risque des transfusions d'érythrocytes}

La transfusion d'érythrocytes demeure la seule façon efficace de traiter une perte de sang peropératoire aiguë grave. L'allotransfusion est associée à des risque infectieux et non infectieux (Tableau). ${ }^{43}$ Parmi les risques infectieux, citons les risques liés à la transmission de divers agents, notamment les virus, les bactéries et les protozoaires. Alors que les risques de transmission par transfusion d'infections virales, telles que le virus de l'immunodéficience humaine (VIH) ou le virus de l'hépatite $\mathrm{C}$, sont extrêmement faibles (par ex., au Canada, le risque de VIH transmis par transfusion est estimé à 1 sur 7,8 millions), ${ }^{44}$ l'émergence de nouveaux pathogènes transmissibles par le sang (comme le virus Chikungunya) constitue une préoccupation grandissante pour la réserve de sang. Les risques non infectieux liés à la transfusion représentent une proportion plus importante d'événements défavorables. Ils peuvent être mineurs (par ex., de l'urticaire) ou graves (par ex., choc anaphylactique). Selon un rapport de la Food and Drug Administration (FDA) américaine datant de 2009, les principales causes de mortalité liée aux transfusions sont les lésions pulmonaires aiguës liées aux transfusions, les réactions hémolytiques aux transfusions, et la surcharge circulatoire associée à une transfusion. De nombreuses études ont confirmé une association entre les allotransfusions et les infections postopératoires, une durée prolongée d'hospitalisation, la morbidité et la mortalité. ${ }^{13-17,43}$ En outre, les allotransfusions ont été associées à un risque accru d'événements thrombotiques ${ }^{45}$ et à une réduction de la survie exempte de maladie chez les patients cancéreux. ${ }^{46}$ En fait, dans une revue méthodique réalisée par Marik et coll., les risques liés à la transfusion étaient supérieurs aux bienfaits dans 42 des 45 études évaluées. ${ }^{47}$ Indépendamment de l'efficacité du maintien du volume intravasculaire et de la capacité de transport d'oxygène du sang, la transfusion d'érythrocytes comporte de nombreux risques. La décision de transfuser ou non devrait se fonder sur des données cliniques et de laboratoire, et les alternatives disponibles devraient être envisagées.

\section{Le diagnostic et le traitement de l'anémie}

Étant donné la quantité de données probantes soutenant que l'anémie et les transfusions d'érythrocytes sont toutes deux associées à une morbidité et une mortalité accrues, une stratégie visant à minimiser ces deux conditions pourrait améliorer de façon significative le pronostic des patients. Ainsi, il convient d'envisager de diagnostiquer et de traiter de façon satisfaisante l'anémie chez les patients devant subir une chirurgie non urgente, comme le soutient un article de synthèse récent ${ }^{11}$ et le recommande le Réseau pour l'avancement des alternatives à la transfusion (Network for Advancement of Transfusion Alternatives - voir figure). Cette approche s'est fondée sur les données probantes suivantes: 1) une proportion élevée de patients sont anémiques lorsqu'ils se présentent pour une chirurgie; 2) la majorité des cas d'anémie sont traitables (carences nutritionnelles, perte de sang, anémie de la maladie chronique); et 3) si le traitement de l'anémie réussit, la transfusion peut être évitée. ${ }^{48,49}$

Tout patient anémique en préopératoire peut être facilement évalué en réalisant un hémogramme complet ainsi qu'une évaluation de la ferritine, de la vitamine B12, et de l'acide folique érythrocytaire. Étant donné que les carences en vitamine B12 et en acide folique sont plus courantes chez les patients âgés, tous les patients âgés de plus de 65 ans et les patients présentant un risque de carences nutritionnelles devraient être évalués. Les carences en vitamine $\mathrm{B} 12$ et en acide folique répondent très bien à un traitement avec des médicaments par voie orale. Un faible taux de ferritine indique invariablement une carence en fer. Malheureusement, un taux élevé de ferritine n'indique pas forcément que les réserves de fer sont pleines. La ferritine est un réactif de phase aiguë et pourrait être élevée dans des états inflammatoires. La saturation de fer sérique n'est pas un test fiable pour évaluer une carence en fer. Toutefois, un récepteur soluble de la transferrine pourrait aider à distinguer une carence en fer d'une anémie de la maladie chronique. Ce marqueur est élevé lors d'une carence en fer et bas ou normal lors d'anémie de la maladie chronique.

Une fois le diagnostic posé, la carence en fer peut être traitée efficacement à l'aide de fer administré par voie orale ou intraveineuse. ${ }^{11,50}$ Chacune des deux préparations possède ses propres avantages et inconvénients, lesquels ont été résumés exhaustivement dans plusieurs publications récentes. ${ }^{51,52}$ Alors que le fer sera efficace pour traiter une anémie ferriprive, l'anémie de la maladie chronique pourrait nécessiter une combinaison de fer et d'agents de stimulation érythrocytaire (ESA) pour améliorer leurs taux de $\mathrm{Hb}$.

\section{L'utilisation des ESA pour traiter l'anémie}

L'utilisation d'ESA, tels que l'érythropoiétine humaine recombinante, a été étudiée comme moyen d'accélérer la correction de la masse érythrocytaire et de réduire efficacement les transfusions érythrocytaires chez les patients subissant une chirurgie cardiaque et orthopédique. ${ }^{10,49,53-56}$ Chez ces populations de patients, il a été démontré que les ESA augmentaient les taux de $\mathrm{Hb}$, réduisaient les allotransfusions, augmentaient la capacité aérobique et amélioraient la qualité de vie. ${ }^{57} \mathrm{La}$ capacité 
Tableau Risques associés aux transfusions

\begin{tabular}{|c|c|c|}
\hline Risque d'une transfusion & Gravité & Incidence \\
\hline $\begin{array}{l}\text { Réaction fébrile non hémolytique à la } \\
\text { transfusion }\end{array}$ & Léger & 1 sur 300 donneurs d'érythrocytes \\
\hline Réaction allergique & Léger à grave & $\begin{array}{l}1 \text { réaction allergique mineure sur } 100 \\
1 \text { réaction allergique majeure sur } 40000\end{array}$ \\
\hline \multicolumn{3}{|l|}{ Infection: } \\
\hline Bactéries & Léger à grave & 1 sur 500000 \\
\hline Virus & Grave & $\begin{array}{l}\text { VIH } 1 \text { sur } 7800000 \\
\text { VHC } 1 \text { sur } 2300000 \\
\text { VHB } 1 \text { sur } 153000 \\
\text { HTLV } 1 \text { sur } 5000000\end{array}$ \\
\hline Autres (protozoaires, prions) & Grave & VNO 1 sur 1000000 \\
\hline Pathogènes émergents & Inconnu & $\begin{array}{l}\text { Inconnu } \\
\text { Inconnu }\end{array}$ \\
\hline Erreur de transfusion & Léger à grave & $\begin{array}{l}1 \text { sur } 1000 \text { événements évité de justesse } \\
1 \text { sur } 15000 \text { cas de sang incorrect donné au receveur } \\
1 \text { sur } 40000 \text { cas de sang incorrect donné au receveur est incompatible ABO } \\
1 \text { sur } 1000000 \text { réaction hémolytique aiguë fatale à la transfusion }\end{array}$ \\
\hline Lésion pulmonaire aiguë liée à la transfusion & Grave & 1 sur 30000 unités \\
\hline Surcharge circulatoire associée à la transfusion & $\begin{array}{l}\text { Modérée à } \\
\text { grave }\end{array}$ & 1 sur 700 épisodes de transfusion \\
\hline Immunomodulation & Léger à grave & Inconnu \\
\hline Décès & Grave & 1 sur 1800000 à 5600000 \\
\hline
\end{tabular}

Sources: O'Brien et coll. ${ }^{44}$ Vamvakas et coll ${ }^{43}$

$\mathrm{VIH}=$ virus de l'immunodéficience humaine; VHC = virus de l'hépatite C; VHB = virus de l'hépatite B; HTLV = virus du lymphome humain à cellules $\mathrm{T} ; \mathrm{VNO}=$ virus du Nil occidental

des ESA à réduire les transfusions a été contrebalancée en raison d'inquiétudes récentes concernant une augmentation des pronostics défavorables (thrombose, progression $d u$ cancer) associés à un traitement à base d'ESA chez les patients subissant une chirurgie du rachis et chez les patients souffrant d'insuffisance rénale chronique et de cancer. ${ }^{58-60}$ Une étude clinique récente a suggéré que l'utilisation chronique d'ESA à fort dosage chez les patients souffrant d'insuffisance rénale pourrait ne pas forcément améliorer leur qualité de vie ou réduire la mortalité. En fait, ce pourrait être le contraire: les ESA pourraient augmenter le risque d'événements thrombotiques artériels (accidents vasculaires cérébraux) et la mortalité chez ces patients. ${ }^{57,58}$ Sur la base de ces nouvelles données, la FDA a publié un avertissement sur tous les produits d'ESA. En outre, la FDA a récemment approuvé une Stratégie d'évaluation et d'atténuation du risque (Risk Evaluation and Mitigation Strategy) qui s'applique à la classe entière des ESA; cette stratégie contraint les médecins prescrivant des ESA aux patients cancéreux à s'inscrire et à suivre une formation spéciale.

Ces études n'appuient pas pour autant l'abandon du traitement de l'anémie chez les patients devant subir une chirurgie non urgente. Chez ces patients, il a été démontré qu'un traitement à base d'ESA réduisait le nombre de transfusions sans augmenter significativement le risque de thrombose. ${ }^{48,53,54}$ Étant donné le risque d'événements défavorables, une approche graduée est suggérée; les ESA sont recommandés pour traiter une anémie ferriprive ne répondant pas au traitement et pour laquelle on suspecte une composante d'anémie de la maladie chronique. ${ }^{10}$ En outre, des études cliniques suggèrent qu'un court traitement et/ou un traitement à faible dose avec des ESA pourrait constituer une façon sécuritaire et efficace d'augmenter la masse érythrocytaire et d'éviter les transfusions érythrocytaires chez les patients anémiques en périopératoire. ${ }^{48,49,55} \mathrm{D}$ 'autres études sont nécessaires afin de déterminer si un traitement vigoureux de l'anémie peut améliorer le pronostic des patients après d'autres types de chirurgie.

Parmi les indications pour l'utilisation d'ESA, citons les chirurgies non urgentes majeures (associées à un risque $>10 \%$ de pertes sanguines requérant une transfusion) chez les patients atteints d'anémie ferriprive et/ou d'anémie de la maladie chronique ne répondant pas au traitement et dont le taux de $\mathrm{Hb}$ au départ est de 100 à 
$120 \mathrm{~g} \cdot \mathrm{L}^{-1}$. L'objectif du traitement est de réduire les allotransfusions et d'accélérer la récupération érythroïde en postopératoire. ${ }^{56} \mathrm{Il}$ ne faudrait pas administrer d'ESA à des patients souffrant de carence en fer à moins qu'une supplémentation adéquate en fer ne soit administrée simultanément. Ceci s'explique par deux raisons: d'une part, les ESA seuls pourraient ne pas être efficaces en l'absence de fer, et d'autre part, certaines études suggèrent que l'érythropoï̀se induite par les ESA chez une personne souffrant d'une carence en fer pourrait entraîner une thrombocytose et un risque accru de thrombose. Le seuil de $\mathrm{Hb}$ le plus sécuritaire se trouve dans une fourchette de valeurs normales de $\mathrm{Hb}$. Si les niveaux de $\mathrm{Hb}$ sont poussés au-delà de $140 \mathrm{~g} \cdot \mathrm{L}^{-1}$, cela pourrait provoquer une augmentation des complications thrombotiques. Enfin, étant donné que l'utilisation d'ESA est associée à des événements thrombotiques, une thromboprophylaxie périopératoire adaptée est essentielle.

En conclusion, la morbidité et la mortalité associées à l'anémie et à la transfusion d'érythrocytes suggèrent qu'une approche plus énergique soit adoptée en ce qui touche au diagnostic et au traitement de l'anémie préopératoire. Le traitement de l'anémie ferriprive à l'aide de suppléments en fer est recommandé avant de réaliser une chirurgie non urgente associée à une augmentation des pertes sanguines. Une supplémentation en fer en combinaison à des ESA pourrait être nécessaire pour corriger une anémie qui ne répond pas au traitement et une anémie de la maladie chronique. En cas de traitement à base d'ESA, une thromboprophylaxie périopératoire est requise afin de réduire le risque de thrombose veineuse.

\section{Cas clinique}

Une femme de 68 ans est évaluée dans une clinique de pré-admission avant de subir une révision non urgente d'une arthroplastie totale de la hanche. Son chirurgien a prévu l'intervention la semaine suivante. Ses antécédents médicaux indiquent de l'hypertension et un infarctus du myocarde ancien. Il y a six ans, elle a subi un pontage aortocoronarien de l'artère mammaire à l'artère descendante antérieure gauche et de la veine saphène à l'artère coronaire droite. Elle souffre actuellement d'une angine de classe II. Elle prend du bisoprolol, du fosinopril et de l'atorvostatine. Des examens de laboratoire ont démontré un taux d'hémoglobine de $90 \mathrm{~g} \cdot \mathrm{L}^{-1}$, mais une numération cellulaire autrement normale. Un échocardiogramme récent a révélé une fonction ventriculaire gauche de grade 2 accompagnée d'une hypokinésie inférieure, et une étude de scintigraphie au thallium persantin a montré un défaut de perfusion inférieur fixe avec des déficits de perfusion inductibles environnants qui semblent normaux sur les images au repos. Des consultants des départements de cardiologie et de chirurgie cardiaque n'ont pas recommandé de traitement supplémentaire.

\section{Directives pour compléter le module de développement professionnel continu (DPC):}

1. Lisez cet article et les quatre références en gras.

2. Allez à: https://www.cpass2.umontreal.ca/selfassessment program/ et sélectionnez le module actuel (Évaluation et traitement de l'anémie préopératoire).

3. Répondez aux questions à choix de réponses concernant le cas clinique.

4. Une fois que vous avez saisi toutes vos réponses, vous aurez accès aux explications d'experts pour tous les choix possibles.

5. Les participants peuvent réclamer un maximum de quatre heures de DPC pour un total de huit crédits sous la Section 3 du programme de DPC du Collège royal des médecins et chirurgiens du Canada.

Funding sources Department of Anesthesia, St. Michael's Hospital, University of Toronto.

Conflicts of interest None

\section{References}

1. Beattie WS, Karkouti K, Wijeysundera DN, Tait G. Risk associated with preoperative anemia in noncardiac surgery: a singlecenter cohort study. Anesthesiology 2009; 110: 574-81.

2. Karkouti K, Wijeysundera DN, Beattie WS. Reducing Bleeding in Cardiac Surgery $(R B C)$ Investigators. Risk associated with preoperative anemia in cardiac surgery: a multicenter cohort study. Circulation 2008; 117: 478-84.

3. Kulier A, Levin J, Moser R, et al. Impact of preoperative anemia on outcome in patients undergoing coronary artery bypass graft surgery. Circulation 2007; 116: 471-9.

4. Tsui AK, Dattani ND, Marsden PA, et al. Reassessing the risk of hemodilutional anemia: Some new pieces to an old puzzle. Can J Anesth 2010; 57: 779-91.

5. Beris P, Munoz M, Garcia-Erce JA, Thomas D, Maniatis A, Van der Linden $P$. Perioperative anaemia management: consensus statement on the role of intravenous iron. Br J Anaesth 2008; 100: 599-604.

6. Bierbaum BE, Callaghan JJ, Galante JO, Rubash HE, Tooms RE, Welch $R B$. An analysis of blood management in patients having a total hip or knee arthroplasty. J Bone Joint Surg Am 1999; 81: 2-10.

7. Guralnik JM, Eisenstaedt RS, Ferrucci L, Klein HG, Woodman $R C$. Prevalence of anemia in persons 65 years and older in the United States: evidence for a high rate of unexplained anemia. Blood 2004; 104: 2263-8.

8. Saleh E, McClelland DB, Hay A, Semple D, Walsh TS. Prevalence of anaemia before major joint arthroplasty and the potential 
impact of preoperative investigation and correction on perioperative blood transfusions. Br J Anaesth 2007; 99: 801-8.

9. Weiss G, Goodnough LT. Anemia of chronic disease. N Engl J Med 2005; 352: 1011-23.

10. Lasocki S, Longrois D, Montravers P, Beaumont C. Hepcidin and anemia of the critically ill patient: bench to bedside. Anesthesiology 2011; 114: 688-94.

11. Pasricha SR, Flecknoe-Brown SC, Allen KJ, et al. Diagnosis and management of iron deficiency anaemia: a clinical update. Med J Aust 2010; 193: 525-32.

12. da Silveira $A D$, Ribeiro RA, Rossini AP, et al. Association of anemia with clinical outcomes in stable coronary artery disease. Coron Artery Dis 2008; 19: 21-6.

13. Steyerberg EW, Mushkudiani N, Perel P, et al. Predicting outcome after traumatic brain injury: development and international validation of prognostic scores based on admission characteristics. PLoS Med 2008; 5: e165.

14. Hebert PC, Wells G, Blajchman MA, et al. A multicenter, randomized, controlled clinical trial of transfusion requirements in critical care. Transfusion Requirements in Critical Care Investigators, Canadian Critical Care Trials Group. N Engl J Med 1999; 340: 409-17.

15. Koch CG, Li L, Duncan AI, et al. Morbidity and mortality risk associated with red blood cell and blood-component transfusion in isolated coronary artery bypass grafting. Crit Care Med 2006; 34: 1608-16.

16. Koch CG, Li L, Sessler DI, et al. Duration of red-cell storage and complications after cardiac surgery. N Engl J Med 2008; 358: 1229-39.

17. Rao SV, Jollis JG, Harrington RA, et al. Relationship of blood transfusion and clinical outcomes in patients with acute coronary syndromes. JAMA 2004; 292: 1555-62.

18. Ragoonanan TE, Beattie WS, Mazer CD, et al. Metoprolol reduces cerebral tissue oxygen tension after acute hemodilution in rats. Anesthesiology 2009; 111: 988-1000.

19. Karkouti K, Djaiani G, Borger MA, et al. Low hematocrit during cardiopulmonary bypass is associated with increased risk of perioperative stroke in cardiac surgery. Ann Thorac Surg 2005; 80: 1381-7.

20. Karkouti K, Beattie WS, Wijeysundera DN, et al. Hemodilution during cardiopulmonary bypass is an independent risk factor for acute renal failure in adult cardiac surgery. $\mathrm{J}$ Thorac Cardiovasc Surg 2005; 129: 391-400.

21. Hebert PC, Yetisir E, Martin $C$, et al. Is a low transfusion threshold safe in critically ill patients with cardiovascular diseases? Crit Care Med 2001; 29: 227-34.

22. McIntyre LA, Fergusson DA, Hutchison JS, et al. Effect of a liberal versus restrictive transfusion strategy on mortality in patients with moderate to severe head injury. Neurocrit Care 2006; 5: 4-9.

23. McLaren AT, Marsden PA, Mazer CD, et al. Increased expression of HIF-1\{alpha\}, nNOS, and VEGF in the cerebral cortex of anemic rats. Am J Physiol Regul Integr Comp Physiol 2007; 292: R403-14.

24. Weiskopf RB, Viele MK, Feiner J, et al. Human cardiovascular and metabolic response to acute, severe isovolemic anemia. JAMA 1998; 279: 217-21.

25. Chapler $C K$, Cain SM. The physiologic reserve in oxygen carrying capacity: studies in experimental hemodilution. Can J Physiol Pharmacol 1986; 64: 7-12.

26. Hare GM, Worrall JM, Baker AJ, Liu E, Sikich N, Mazer CD. Beta2 adrenergic antagonist inhibits cerebral cortical oxygen delivery after severe hemodilution in rats. Br J Anaesth 2006; 97 : 617-23.

27. Beattie WS, Wijeysundera DN, Karkouti K, et al. Acute surgical anemia influences the cardioprotective effects of beta-blockade: a single-center, propensity-matched cohort study. Anesthesiology 2010; 112: 25-33.

28. POISE Study Group, Devereaux PJ, Yang H, et al. Effects of extended-release metoprolol succinate in patients undergoing non-cardiac surgery (POISE trial): a randomised controlled trial. Lancet 2008; 371: 1839-47.

29. van Klei WA, Bryson GL, Yang H, Forster AJ. Effect of betablocker prescription on the incidence of postoperative myocardial infarction after hip and knee arthroplasty. Anesthesiology 2009; 111: 717-24.

30. Weiskopf RB, Kramer JH, Viele M, et al. Acute severe isovolemic anemia impairs cognitive function and memory in humans. Anesthesiology 2000; 92: 1646-52.

31. Conlon NP, Bale EP, Herbison GP, McCarroll M. Postoperative anemia and quality of life after primary hip arthroplasty in patients over 65 years old. Anesth Analg 2008; 106: 1056-61.

32. Dunkelgrun M, Hoeks SE, Welten GM, et al. Anemia as an independent predictor of perioperative and long-term cardiovascular outcome in patients scheduled for elective vascular surgery. Am J Cardiol 2008; 101: 1196-200.

33. Halm EA, Wang JJ, Boockvar K, et al. The effect of perioperative anemia on clinical and functional outcomes in patients with hip fracture. J Orthop Trauma 2004; 18: 369-74.

34. Transfusion. Lancet $1825 ; 4: 342-3$.

35. Gray C. Long before Krever's report, blood scare had changed face of medicine. CMAJ 1998; 158: 89-91.

36. Hajjar LA, Vincent JL, Galas FR, et al. Transfusion requirements after cardiac surgery: the TRACS randomized controlled trial. JAMA 2010; 304: 1559-67.

37. Shehata N, Mazer $C D$, Thorpe KE. Blood transfusion and cardiac surgery. JAMA 2011; 305: 357-8.

38. Creteur J, Neves AP, Vincent JL. Near-infrared spectroscopy technique to evaluate the effects of red blood cell transfusion on tissue oxygenation. Crit Care 2009; 13(Suppl 5): S11.

39. Dhar R, Zazulia AR, Videen TO, Zipfel GJ, Derdeyn CP, Diringer $M N$. Red blood cell transfusion increases cerebral oxygen delivery in anemic patients with subarachnoid hemorrhage. Stroke 2009; 40: 3039-44.

40. Zygun DA, Nortje J, Hutchinson PJ, Timofeev I, Menon DK, Gupta AK. The effect of red blood cell transfusion on cerebral oxygenation and metabolism after severe traumatic brain injury. Crit Care Med 2009; 37: 1074-8.

41. Kiraly LN, Underwood S, Differding JA, Schreiber MA. Transfusion of aged packed red blood cells results in decreased tissue oxygenation in critically injured trauma patients. J Trauma 2009; 67: 29-32.

42. Wu WC, Smith TS, Henderson WG, et al. Operative blood loss, blood transfusion, and 30-day mortality in older patients after major noncardiac surgery. Ann Surg 2010; 252: 11-7.

43. Vamvakas EC, Blajchman MA. Transfusion-related mortality: the ongoing risks of allogeneic blood transfusion and the available strategies for their prevention. Blood 2009; 113: 3406-17.

44. O'Brien SF, Yi QL, Fan W, Scalia V, Kleinman SH, Vamvakas $E C$. Current incidence and estimated residual risk of transfusiontransmitted infections in donations made to Canadian Blood Services. Transfusion 2007; 47: 316-25.

45. Khorana AA, Francis $C W$, Blumberg $N$, Culakova E, Refaai MA, Lyman $G H$. Blood transfusions, thrombosis, and mortality in hospitalized patients with cancer. Arch Intern Med 2008; 168: 2377-81.

46. Vamvakas EC, Blajchman MA. Deleterious clinical effects of transfusion-associated immunomodulation: fact or fiction? Blood 2001; 97: 1180-95.

47. Marik PE, Corwin HL. Efficacy of red blood cell transfusion in the critically ill: a systematic review of the literature. Crit Care Med 2008; 36: 2667-74. 
48. de Andrade JR, Frei D, Guilfoyle M. Integrated analysis of thrombotic/vascular event occurrence in epoetin alfa-treated patients undergoing major, elective orthopedic surgery. Orthopedics 1999; 22(1 Suppl): s113-8.

49. Feagan BG, Wong CJ, Kirkley A, et al. Erythropoietin with iron supplementation to prevent allogeneic blood transfusion in total hip joint arthroplasty. A randomized, controlled trial. Ann Intern Med 2000; 133: 845-54.

50. Theusinger OM, Leyvraz PF, Schanz U, Seifert B, Spahn DR. Treatment of iron deficiency anemia in orthopedic surgery with intravenous iron: efficacy and limits: a prospective study. Anesthesiology 2007; 107: 923-7.

51. Auerbach $M$, Ballard H, Glaspy J. Clinical update: intravenous iron for anaemia. Lancet 2007; 369: 1502-4.

52. Shander A, Spence RK, Auerbach M. Can intravenous iron therapy meet the unmet needs created by the new restrictions on erythropoietic stimulating agents? Transfusion 2010; 50: 719-32.

53. Alghamdi AA, Albanna MJ, Guru V, Brister SJ. Does the use of erythropoietin reduce the risk of exposure to allogeneic blood transfusion in cardiac surgery? A systematic review and metaanalysis. J Card Surg 2006; 21: 320-6.

54. Garcia-Erce JA, Cuenca J, Haman-Alcober S, Martinez AA, Herrera A, Munoz $M$. Efficacy of preoperative recombinant human erythropoietin administration for reducing transfusion requirements in patients undergoing surgery for hip fracture repair. An observational cohort study. Vox Sang 2009; 97: 260-7.

55. Na HS, Shin SY, Hwang JY, Jeon YT, Kim CS, Do SH. Effects of intravenous iron combined with low-dose recombinant human erythropoietin on transfusion requirements in iron-deficient patients undergoing bilateral total knee replacement arthroplasty. Transfusion 2011; 51: 118-24.

56. Testa $U$. Erythropoietic stimulating agents. Expert Opin Emerg Drugs 2010; 15: 119-38.

57. Hare GM, Baker JE, Mazer CD. Perioperative management of acute and chronic anemia: has the pendulum swung too far? Can J Anesth 2009; 56: 183-9.

58. Pfeffer MA, Burdmann EA, Chen CY, et al. A trial of darbepoetin alfa in type 2 diabetes and chronic kidney disease. N Engl J Med 2009; 361: 2019-32.

59. Rizzo JD, Somerfield MR, Hagerty KL, et al. Use of epoetin and darbepoetin in patients with cancer: 2007 American Society of Hematology/American Society of Clinical Oncology clinical practice guideline update. Blood 2008; 111: 25-41.

60. Stowell CP, Jones SC, Enny C, Langholff W, Leitz G. An openlabel, randomized, parallel-group study of perioperative epoetin alfa versus standard of care for blood conservation in major elective spinal surgery: safety analysis. Spine 2009; 34: 2479-85. 